https://doi.org/10.30910/turkjans.727892

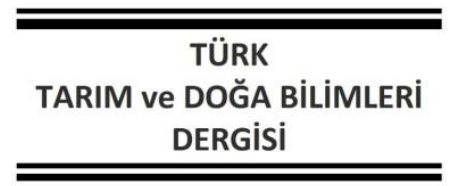

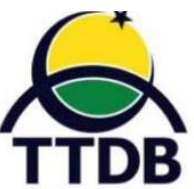

www.dergipark.gov.tr/turkjans

\title{
Research Article \\ Stolbur and Clover Proliferation Phytoplasma Infections in Tomato from Bingöl Province, Turkey
}

\author{
Abdullah GÜLLER ${ }^{1 *}$, Mustafa USTA² \\ ${ }^{1}$ Bingöl University, Faculty of Agriculture, Department of Plant Protection, Bingol \\ ${ }^{2}$ Van Yüzüncü Yıl University, Faculty of Agriculture, Department of Plant Protection, Van \\ *Corresponding Author: aguller@bingol.edu.tr
}

\section{Received: 27.04.2020 Revised in received: 24.09.2020 Accepted: 09.10.2020}

\begin{abstract}
Phytoplasma-type symptoms were noted in tomato (Lycopersicum esculentum L.) in Bingöl province of Turkey. The remarkable symptoms include witch's broom, rosetting, purple curled and crispy leaves, small leaves in the upper branches and excessively elongated calyx. Genomic DNA isolation was performed to identify possible pathogens from the leaves of 11 plants with and without symptom. In the Nested-PCR test performed using universal primer sets, DNA bands of approximately $1200 \mathrm{bp}$ size were obtained in 4 of 11 samples. Randomly chosen two DNA bands primed R16F2n/R16R2 were cloned into an appropriate plasmid vector to further characterizations. The recombinant plasmid DNAs purified were sequenced in both directions. Molecular assays of the $16 \mathrm{~S}$ rRNA sequence confirmed the existence of the "Canditatus Phytoplasma solani" (16SrXII-A group) (similarity coefficient 1.00) (Accession no: MT279680) and the "Canditatus Phytoplasma trifolii" (16SrVI-A group) (similarity coefficient 1.00) (Accession no: MT279852) in the infected tomato samples. The isolates associated with tomato-phytoplasma were named as 'Bingöl D11' and 'Bingöl D90' isolates, respectively. The phylogenetic dendrogram created also confirmed where both pathogens belong.

This current paper is documented in the first record of "Ca. P. solani" (16SrXII-A) and "Ca. P. trifolii" (16SrVI-A) in naturally diseased tomato in Bingöl of Turkey.
\end{abstract}

Key words: “Ca. P. solani”, “Ca. P. trifolii”, Virtual RFLP, 16S rRNA gene, tomato

\section{Bingöl İlinde Domateste Stolbur ve Yonca Proliferasyon Fitoplazma Enfeksiyonları}

\section{Öz}

Bingöl ilinde yetiştiriciliği yapılan domates (Lycopersicum esculentum L.) tarlalarında fitoplazma benzeri belirtiler dikkat çekmiştir. Dikkat çeken belirtiler arasında cadı süpürgesi, rozetleme, mor renkli kıvrılmış ve gevrek yapraklar, üst dallarda küçük yapraklılık ve aşırı uzamış kaliks yer almaktadır. Simptomlu ve simptomsuz toplam 11 bitkinin yapraklarından muhtemel patojeni belirleyebilmek için genomik DNA izolasyonu yapılmıştır. Üniversal primer setleri kullanılarak gerçekleştirilen Nested-PCR testlerinde, 11 örneğin 4'ünde yaklaşık 1200 bp büyüklüğünde DNA bantları elde edilmiştir. R16F2n/R16R2 primerleri ile bant veren örneklerden rastgele ikisi seçilerek uygun bir plasmid vektörde klonlanmıştır. Saflaştırılan rekombinant plasmid DNA'sı çift yönlü olarak dizilenmiştir. 16S rDNA dizisinin moleküler analizleri, infekteli domates örneklerinde 'Canditatus Phytoplasma solani' (16SrXII-A grup) (benzerlik katsayısı 1.00) (Ulaşım no: MT279680) ve 'Canditatus Phytoplasma trifolii'(16SrVI-A grup) (benzerlik katsayısı 1.00) (Ulaşım no: MT279852) doğrulamıştır. Domates örneklerindeki fitoplazma izolatları 'Bingöl D11' ve 'Bingöl D90' olarak isimlendirilmiştir. Oluşturulan filogenetik dendrogram da her iki patojenin ait olduğu yeri doğrulamıştır.

Mevcut bu çalışma Bingöl ilinde domatesi doğal olarak enfekte eden “Ca. P. solani”(16SrXII-A) ve “Ca. P. trifolii"(16SrVI-A) nin ilk raporudur.

Anahtar kelimeler: “Ca. P. solani”, “Ca. P. trifolii”, Virtual RFLP, 16S rRNA geni, Domates 


\section{Introduction}

In Turkey and the world, tomato (Lycopersicum esculentum L.) is one of the most important products with commercial potential. It is considered one of the vegetables widely grown in most regions worldwide (Sertkaya et al., 2007). Tomato health can be impaired by many pests as well as many viral, fungal and bacterial agents. Tomato is subjected to phytoplasma infection within Canditatus Phytoplasma genus grouped in Mollicutes class, known as formerly mycoplasmalike organisms. This is an economically important bacterial disease worldwide and the most persistent common problem in tomato farming (Shaw and Kirkpatrick, 1993). Phytoplasmas, explored in 1967, are biotrophic aggressive parasitic prokaryotes, only restricted to phloem sieves of their host plants, without cell walls (with a 3-layer membrane, 8-10 nm in size) (Hull, 1972; Schneider et al., 1999), in vitro or in vivo unculturable although someone claims the opposite (Contaldo et al., 2012).

The systemic phytopathogen is recognized by a large number of diseases by affecting many plants including vineyard, fruit trees, ornamental plants, and vegetables, as well as insects (Çağlar and Elbeaoino, 2013; Ember et al., 2011; Pracros et al., 2006; Gazel et al., 2016, Weisburg et al., 1989; Oshima et al., 2013).

Phytoplasmas systemically spread in host plants and distributed from plant to plant by insects feeding phloem sap at persistent mode (Thylocyba quercus, Hyalestes obsoletus, Macrosteles laevis, Circulifer haematoceps, and Pentastridius leporinus) (Şahin et al., 2007; Weintraub and Jones, 2010), weeds (Setaris spp., Datura stromonium, Polygonum persicaria, Amaranthus albus) and parasitic plants (Orobanche ramosa, Cuscuta campestris) (Afat, 2004; Özdemir, 2008).

Symptoms of phytoplasmas on tomato plants usually occur in flowers, leaves, and fruits. The initial symptoms of the leaves include slight violet color and reduced leaf size of growing young shoots, and twisting in advanced stages (Del Serrone et al., 2001). The infection strongly and prominently affects flower morphology. No flowers are formed before the inflorescence in early infections. Abnormal growth in sepals results in male and female organ sterility. In late infection, fertilized flowers can turn into fruit before the incubation period of the pathogen (Valente et al., 1961; Tsplenkov and Fedotina, 1973). But, their structures are completely hard (woody), tasteless, colorless, dehydrated and without seeds. It also exhibits stunted and growth retardation due to impaired transport of assimilation products in pathogen-infected plants (Usta et al., 2018). The defective agent severely destroys tomato fruits, rendering them unmarketable (Çarpar and Sertkaya, 2015; Musetti et al., 2013; Liu et al., 2016).

TEM imaging, ELISA assays, and DNA based methodology such as (polymerase chain reaction, hybridization) are frequently used diagnostic methods (Kanatiwela-de Silva et al., 2019; Gopala and Rao, 2018). To date, especially the 16s rRNA gene highly conserved in prokaryotes was used to distinguish the phytoplasma group/subgroup as a conventionally marker gene in numerous research. Besides, immunodominant membrane proteins (imp), elongation factor (tuf), ribosomal protein (rp), chaperonin (cpn60), protein translocase subunit (secY), RNA polymerase $\beta$ subunit (rpoB), and secreted aster yellows phytoplasma strain witches' broom (AY-WB) protein 11 (SAP11) genes have been preferred by various researchers as supportive tools for more detailed classification of phytoplasma strains (Davis et al., 2013; Alvarez et al., 2014; Pérez-López et al., 2014; Al-Subhi et al., 2017).

Based on the analysis of the 16s rRNA gene, taxonomy of phytoplasma was divided into 33 separate groups, mostly subgroups. Phytoplasma infection of tomato is reported from distinct phytoplasma groups in various countries. Canditatus Phytoplasma solani ("Ca. P. solani") in Stolbur (16SrXII group) and Canditatus Phytoplasma trifolii ("Ca. P. trifolii") in Clover proliferation (16SrVI group) are two important pathogens in infected tomato inducing similar symptoms (Bertaccini et al, 2014). Tomato plants showing classical phytoplasma symptoms were also recorded anywhere in Turkey, but its presence in Bingöl province is unknown. Suspicious tomato plants exhibiting phytoplasma-like symptoms were observed from tomato planted fields in Bingöl province during 2019 growing season. The presence and group of possible phytoplasma agents were investigated using 16s rRNA ribosomal gene by utilizing molecular tools as PCR and virtual RFLP analysis and revealed the phylogenetic relationship based on related genes.

\section{Materials and Methods}

Biological material and detection of the causal
agent
Tomato growing fields in central-Bingöl province were the focus of phytoplasma investigations conducted in 2019. During the course of surveys in late August, leaf samples were collected from a total of 4 symptomatic and 7 
asymptomatic tomato plants (probably noinfection) for comparative purposes. Samples were put into the plastic bag and stored at $-20{ }^{\circ} \mathrm{C}$ until DNA isolation. The occurrence of potential pathogen in tested specimens were evaluated using DNA isolation and PCR assay.

All DNAs were isolated from $0.5 \mathrm{~g}$ of frozen tissue using the Thermofisher Plant DNA Extraction kit. The PCR tests targeting the 16S rDNA gene were carried out in two steps using two different universal primer pairs: direct PCR (d-PCR) and nested PCR (n-PCR). In the first step, P1/P7 primers were used (Schneider et al., 1995). The second step was carried out with R16F2n/R16R2 (Arocha et al., 2005) to determine the pathogen present in the plant tissues at low titer (Olmos et al., 1999). The reaction parameters, temperature cycles, and phytoplasma positive control were used as mentioned by Usta et al. (2017). DNA isolated from healthy tomato plants was used as a negative control. Amplified d-PCR yields were diluted 30folds using distilled water and used as target DNA for n-PCR tests.

Expected length n-PCR yields were run on horizontal $1.5 \%$ agarose gel buffered in $1 \times$ TAE (Tris Acetic EDTA, pH 8.0) added with ethidium bromide dye (\%1), with a 10kb DNA marker and, displayed with a UV documentation system (Syngene).

\section{Cloning and Nucleotide Sequencing}

The phytoplasma-related 16S rDNA amplicons amplified by $n-P C R$ was recovered from agarose gel with Thermofisher Gel Extraction kit (Waltham, MA, USA) as described by the manufacturer. Purified pure DNAs were cloned into pGEM T-Easy Vector using T-A cloning method and transformed into competent $E$. coli bacteria (Promega, USA) by micropulser device. Two whitecolored isolates containing insert DNA were selected and the recombinant plasmids from transformed bacteria were purified (Thermofisher Plasmid Miniprep Kit). The 16S rRNA sequences in bi-directional sequenced plasmids were deposited to NCBI (Bethesda, MD, USA).

\section{Sequence identity of 16S rRNA gene and phylogenetic analysis}

The 16S rDNA gene sequences identity of Bingöl isolates were identified using the BLASTN program with the nucleotide sequence deposited in NCBI. The similarity coefficient and detection of group/subgroup of Bingöl isolate were conducted using the current version of the iPhyclassifier online software (Wei et al., 2007).

The isolates of this study along with the $16 \mathrm{~S}$ rRNA sequence of 26 isolates belonging to diverse phytoplasma groups archived in the GenBank were used to create the phylogenetic tree. The phylogenetic dendrogram was constructed by the Mega 7 program using the Neighbor-Joining method, with bootstrapped 1000 folds. Acholeplasma laidlawii, a culturable bacteria phylogenetically associated with Mollicutes, was used as the outsource to root the tree.

\section{Virtual RFLP analysis}

The restriction enzyme digestion and virtual RFLP patterns of $16 S$ rDNA genes were automatically analyzed using different seventeen restriction endonucleases enzymes as described by Lee et al., 1998 by the pDRAW32 software (Zhao et al., 2009). Generated in silico pattern of tomato phytoplasma was matched with "Ca. P. solani" (16SrXII-A, AF248959) and "Ca. P. trifolii" (16SrVI$A, A Y 390261)$ reference isolate accepted previously for group/subgroup discrimination.

\section{Results}

Symptoms on diseased plants, Nested-PCR, Sequence similarity

Tomato symptoms were observed, i.e severe fruit deformation, flower sterility, little leaf, purplish, and thickened leaves, hypertrophied calyx, and leaf rolling, recalling those characteristics triggered by phytoplasma attacks in tomato fields in Bingöl province of Turkey in 2019 (Fig 1). 

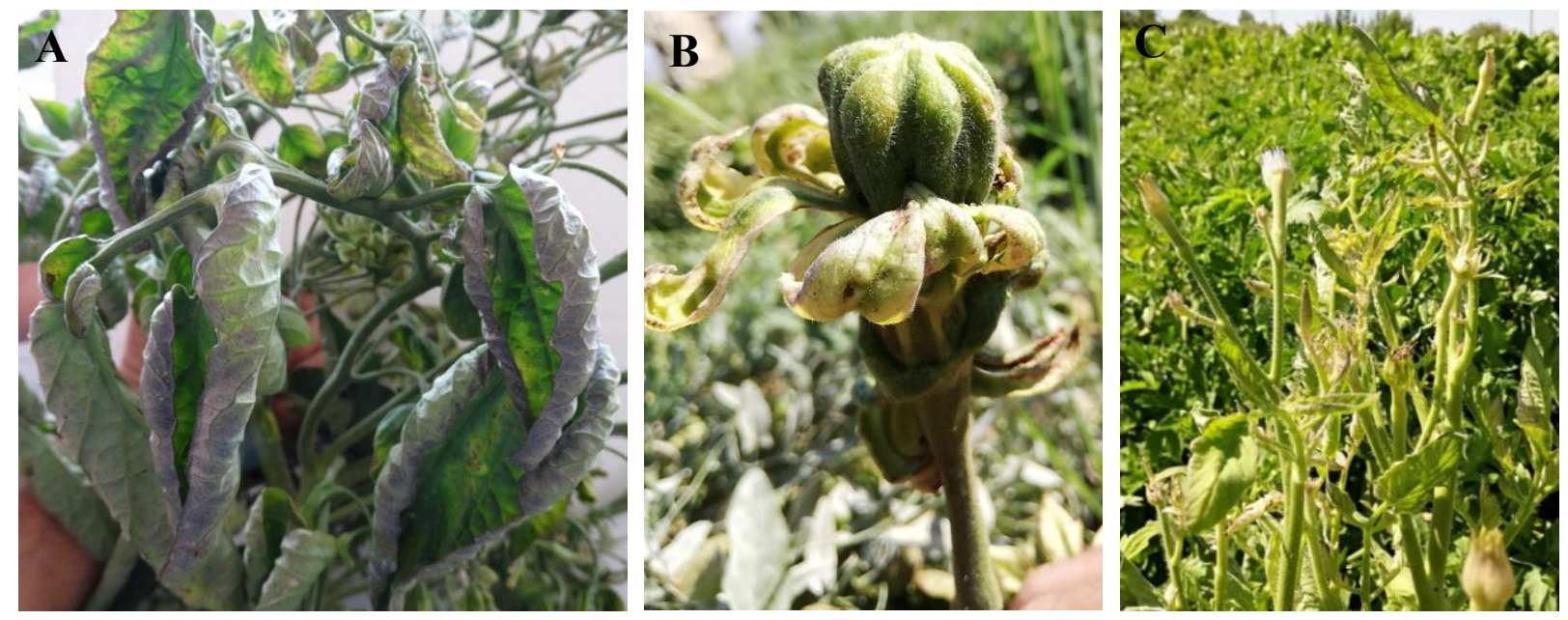

Figure 1. Severely phytoplasma symptoms in naturally diseased tomato plants under field conditions. (A) Purplish leaves curled upward on infectious plants, (B) Big bud symptoms and fruit sterility, (C) Floral phyllody.

Eleven tomato plants collected were screened with R16F2n/R16R2 by $n-P C R$ to determine probable phytoplasma occurrence. As shown in Fig 2, four of them produced positive results displaying typical an approx. $1.25 \mathrm{~kb}$ DNA fragment. Phytoplasmic presences in tomato were confirmed by the correct bp size of the DNA fragments. All of the symptomatic samples gave positive reactions for phytoplasma in $n-P C R$, but healthy tomato plant was not.

The amplicons of two randomly selected isolates were sequenced bidirectinally after cloned in the pGEM T-Easy vector. The 16S rRNA sequences trimmed from the recombinant plasmid were $1247 \mathrm{bp}$ and $1250 \mathrm{bp}$ in size. The $1247 \mathrm{bp}$ nucleotide sequence for " $C a$. P. solani" and the $1250 \mathrm{bp}$ nucleotide sequence for "Ca. P. trifolii" were called as 'Bingöl D11' and 'Bingöl D90', respectively. Related sequences were submitted to
GenBank with MT279680 and MT279852 accession number, respectively. The BLASTN program revealed the highest sequence identity ranging from $99-100 \%$ for both sequences, $100 \%$ for Bingöl-solani isolate and $99.68 \%$ for Bingöl-trifolii isolate. Further analysis by iPhyclassifier program as the supportive program also revealed that one of the tomato isolates was in Stolbur group A subgroup (16SrXII-A) and the other was in Clover proliferation group (16SrVI-A) with similarity coefficient 1.00 for both, in close relationship with representative strains; AF248959 (16SrXII-A) and AY390261 (16SrVI-A). According to the CLC Main Workbench program, the 16S rRNA sequence of “Ca. P. trifolii" isolate (Bingöl D90, MT279852) was slightly incompatible with those of other " $\mathrm{Ca}$. P. trifolii" isolates from different accession numbers due to the minor percentage difference.

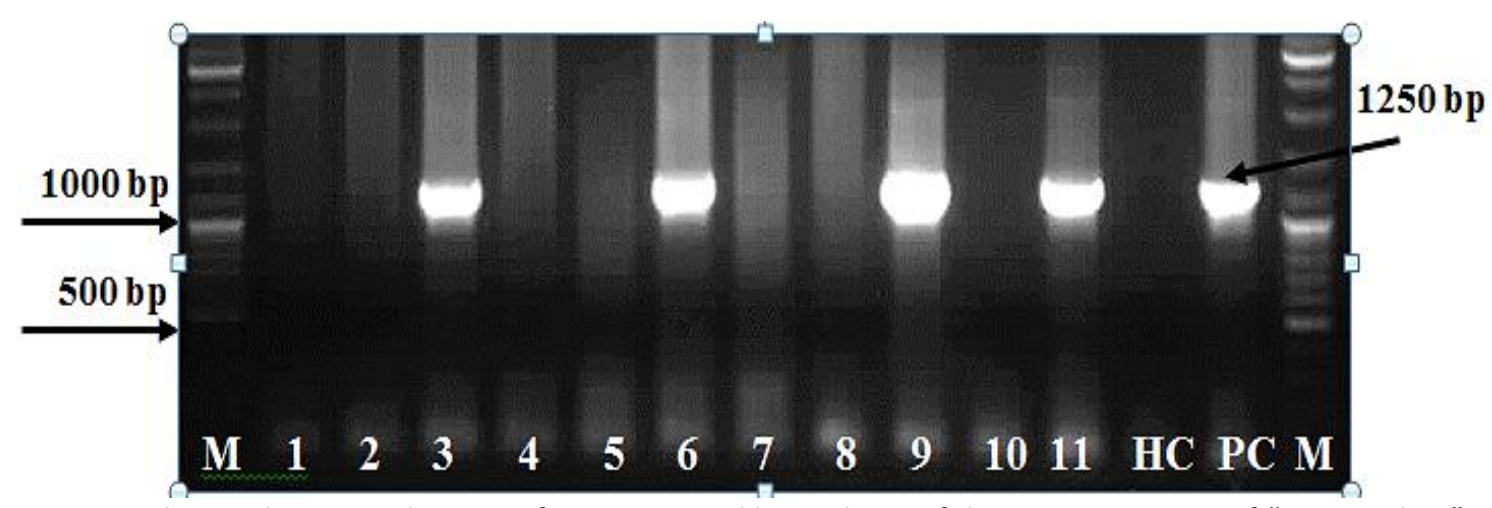

Figure 2. Electrophoresis gel image of approx. $1.25 \mathrm{~kb}$ amplicon of the $16 \mathrm{~S}$ rRNA gene of "Ca. P. solani” and "Ca. P. trifolii" amplified by n-PCR using R16F2n/R16R2 primer pairs. Row 1-11 are tested fresh tomato leaf samples, 3, 6, 9, and 11: Positively reacted samples, HC: Healthy control, PC: Positive control associated with phytoplasma, M:10.000 bp markers. 


\section{Virtual RFLP and Phylogenetic relationship}

The sequences of R16F2n/R16R2 primed PCR product were digested in silico using 17 digestion enzymes by the computer-simulated program. Bingöl phytoplasmas detected in this study were identical with RFLP models previously defined for subgroup 16SrXII-A members (Quaglino et al., 2013) and subgroup 16SrVI-A members (Hiruki et al., 2004). The virtual gel images of both isolates in tomato are available in Fig 3.

"Ca. Phytoplasma trifolii" Bingöl D90 isolate (MT279852) Similarity coefficient:1.00

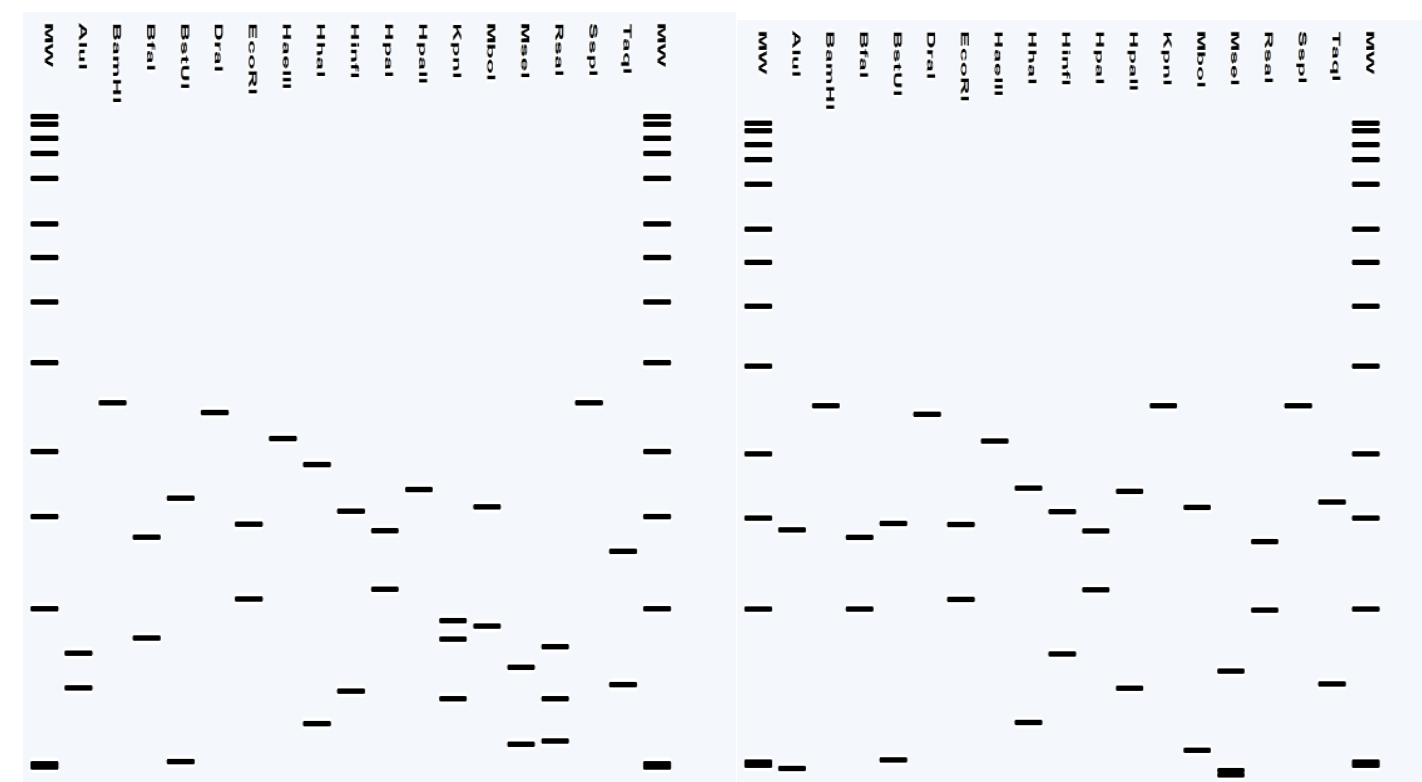

Figure 3. The virtual RFLP pattern created from the $16 \mathrm{~S}$ rDNA fragment (similarity coefficient 1.00) of Bingöl tomato isolates, "Ca. P. solani" (MT279680) and "Ca. P. trifolii" (MT279852) based on reference isolates with accession number AF248959 (16SrXII-A) and AY390261 (16SrVI-A), MW: 1 kb DNA marker

The 16s rRNA sequences of Bingöl isolates were aligned and analyzed with sequences from 26 phytoplasmas representing the present phytoplasma group. Phylogenetic analysis of the amplification products of approx 1250 bp confirmed their origins that sequences of MT279680 and MT279852 were closely associated with "Ca. P. solani" isolates and "Ca. P.trifolii" from representative isolates (AF248959 and AY390261). As shown in Fig. 4, Bingöl isolates were also clustered in the same group with other representative phytoplasma isolates from the Stolbur (16S XII-A) and Clover proliferation group (16S VI-A) (indicated by red circle). 


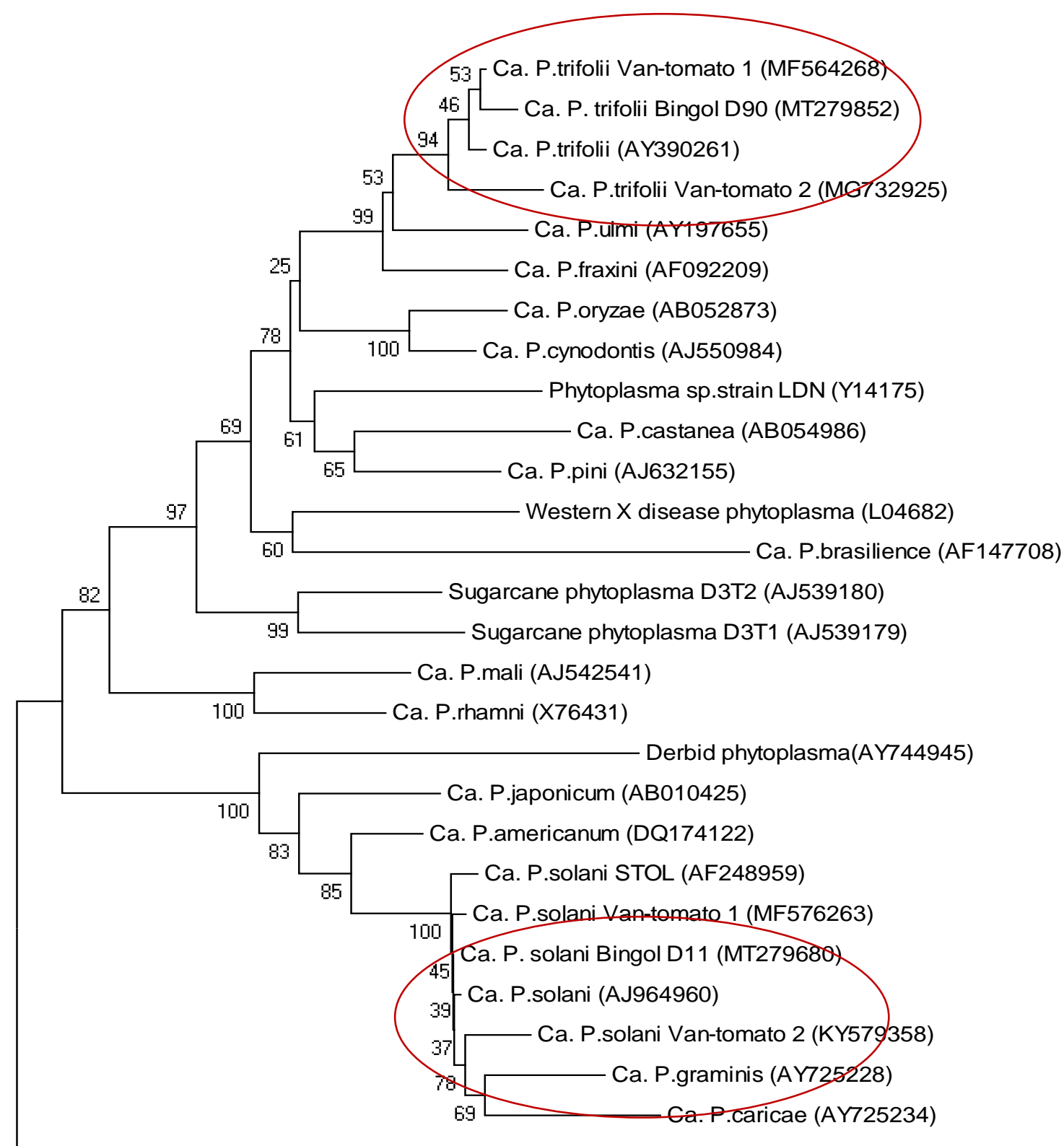

Achopleplasma laidlawii (M23932)

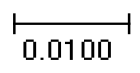

Figure 4. Phylogenetic relationships among $16 \mathrm{~S}$ rDNA sequences of Bingöl isolates and selected phytoplasmas, taken from the NCBI database, created by the neighbor-joining algorithm. A. laidlawii was chosen as an outgroup to branch the phylogenetic tree. The numbers of each branch explain bootstrap scores.

\section{Discussion}

Phytoplasmas are biotrophic systemic pathogens that cause infectious in numerous plants. Rising phytoplasma diseases pose a great threat that restricts agriculture production in the ecosystem of Turkey. Phytoplasma associated diseases have been surveyed in vegetable, orchards, ornamental plants, and field crops in different locations of Turkey. Stolbur in potatoes and tomatoes (Alp et al., 2016; Nogay et al., 1988; Sahtiyancı, 1972; Yorgancı et al., 1991; Özdemir et al., 2007; Nogay and Ternar, 1986), Apple proliferation (AP) and Pear Decline (PD) in pome fruits (Canik and Ertunç, 2007; Canik et al., 2009; Yavuz et al., 2019; Gazel et al., 2007), European stone fruit yellows (ESFY) in stone fruits (Çağlayan et al., 2011; Ulubas-Serce et al., 2012; Ulubas-Serce et al., 2006), Flavescense Doree (FD) and Bois Noir (BN) diseases (Grapevine yellows phytoplasmas) (Canik et al., 2011) are important disease detected in our country. Among the vegetables, the family 
of Solanaceae is more commonly infected by " $\mathrm{Ca}$. P. asteris" worldwide (Kumari et al, 2019).

Tomato is one of the important economic crops infected by phytoplasmas in the different $16 \mathrm{Sr}$ groups. Phytoplasma diseases of tomato are attributed to different bacterial hosts worldwide, including "Ca. P. asteris" (Krawczyk et al., 2010), “Ca. P. aurantifolia” (Dong et al., 2013), “Ca. P. australasia" (Singh et al., 2012), "Ca. P. pruni" (Amaral-Mello et al., 2006), "Ca. P. trifolii" (Anfoka et al., 2003), "Ca. P. ulmi" (Del Serrone et al., 2001), “Ca. P. solani” (Usta et al., 2018), and "Ca. P. lycopersici" (Arocha et al., 2007). Although this is so, symptoms triggered by them are essentially very close to each other, in harmony with our study (Fig 1) including big bud, virescence, dwarfing, yellowing or purpling of leaves, overgrowth calyx, and abnormal adventitious shoots, due to the upsetting of the balance of plant hormones (Bertaccini et al., 2005; SantosCervantesa et al., 2007; Xu et al., 2013).

Based on the amplification of the 16S rRNA gene used as a specific marker, we characterized the 16S rRNA gene structure of " $\mathrm{Ca}$. P. solani 'Bingöl D11' (MT279680) and “Ca. P. trifolii” 'Bingöl D90' (MT279852) isolates which are responsible for the phytoplasma disease in tomato. Both of them are prevalent bacterial agents found infecting tomato in the Stolbur group (16 SrXII) and Clover proliferation group (16 SrVI) of phytoplasma taxonomy, respectively (Bertaccini et al., 2014). The tomato-associated phytoplasma disease was first detected by Tanrıkut (1953) in central Anatolia as symptomatologically and then molecularly reported from various provinces of Turkey including Kayseri, Sivas, Kahramanmaraş, Adana (Çağlar et al., 2010), Van (Usta et al., 2018), Adana, Hatay (Sertkaya et al., 2007), Bursa and Çanakkale (Özdemir and Saygılı, 2012). "Ca. P. solani”, which is the cause of quarantine, is infectious in economically value crops such as tomato, grapevine, pepper, eggplant, corn, potato, and beet (Jovic et al., 2009; Belli et al., 2010; Quaglino et al., 2013 Amaral-Mello et al., 2006; Mitrovic et al., 2016; Ember et al., 2011; Del Serrone et al., 2001; Vellios and Lioliopoulou, 2007, Azza and Mohamed Eman, 2016).

"Ca. P. trifolii" is also prevalent pathogen for various hosts in Asia, Europe and, American continents, including tomato in Jordan (Anfoka et al., 2003), pepper in Mexico (Reveles-Torres et al., 2018), grapevine, tomato, soybean, safflower in Iran (Shahryari et al., 2019; Ghayeb Zamharir and Aldaghi, 2018; Salehi et al., 2008; Davoodi et al., 2019), cabbage, sesame, periwinkle, eggplant, pepper in Turkey (Oksal et al., 2017; Ulubaş Serçe and Yılmaz, 2019; Özdemir, 2017; Sertkaya et al.,
2007), in American Elm (Ulmus americana L.) in U.S.A (Flower et al., 2018), willow in China (Zhang et al., 2012), grapevine in Italy (Zambon et al., 2018).

The 16S rRNA gene sequencing outputs of both phytoplasmas from Bingöl province were analyzed by different methodologies. The PCR tests carried out using universal primers and then cloning of amplified products, and nucleotide sequencing brought out the occurrence of related agents in tomato. The use of sequence data is still a practical tool in researching phytoplasma characterization (Lou et al., 2013). The RFLP profiling of $16 \mathrm{~S}$ rRNA gene sequences acts as an essential tool for determining, grouping, and discrimination of phytoplasmic strains (Zhao et al. 2009). Therefore, combining these techniques can provide a precise diagnosis to predict and detect phytoplasmic outbreaks (Wu et al., 2010). According to the virtual RFLP pattern and sequence identity, the current study revealed that the occurrence of two plant phytoplasma agents on the tomato of Bingöl province belongs to the 16SrXII-A Stolbur and 16SrVI-A Clover proliferation group.

In agreement with the findings of the RFLP assays, the phylogenetic dendrogram constructed with 26 phytoplasma strains placed also both isolates within the same cluster along with model strains namely "Ca. P. solani" (AF248959) and "Ca. P. trifolii'” (AY390261). The Bingöl-solani isolate was clustered with Turkish-Van isolate in tomato (MF576263) and Spanish isolates (AJ964960) in grapes (Vitis vinifera), whereas Bingöl-trifolii isolate was closely related to Turkish-Van isolates (MF564268 and MG732925) phylogenetically along with own model strains.

Multiple infections of phytoplasmas have been defined in the plant kingdom (Olivier et al., 2011; Seemuller et al., 2010) and insect vectors (Weintraub and Beanland, 2006). In our previous studies, "Ca. P. solani" and "Ca. P. trifolii" were detected simultaneously in the same cucumber plant (Usta et al., 2017). The presence of both infections associated with solanaceous crops is a ubiquitous situation. The infection of the same plant associated with different phytoplasmas/viruses have also been reported by Kumari et al, (2019). Based on the presence of two agents in this study, it can be suggested that it would probably be possible to detect both pathogens in the same plant if DNA isolation from different parts of the same plant and more sequencing were performed.

Phytoplasma diseases cause irreversible crop losses due to extremely virulence and may turn into a progressive danger from one year to 
another especially in vegetables. It is not controlled by known chemical methods and today there is no method for treating phytoplasmainfected plants. This situation primarily raises the effective control strategies against weeds and vectors having an effect as a source of pathogen and ensuring disease surveillance. Besides both ways, the removal of diseased plant remains, and not planting side by side with infected fields can minimize crop and financial loss by preventing it from making an epidemic. Further studies are needed to specify whether both pathogens in tomatoes are found in other vegetables, weeds, and insect vectors in Bingöl province.

Conflict of Interest Statement: The manuscript's authors declare that, they do not have any conflict of interest.

\section{Researchers' Contribution Rate}

Statement Summary: The authors declare that, they have contributed equally to the manuscript.

\section{References}

Afat, F. 2004. Çanakkale Ilinde Domates Stolbur Hastalığının Yaygınlık Durumunun Belirlenmesi ve Hastalığın Aşı Yoluyla, Küskütle ve Tohumla Taşınma Oranlarının Saptanması. Y. Lisans Tezi. Çanakkale Üniversitesi, Ziraat Fakültesi, Bitki Koruma Bölümü. 58 sayfa.

Alp, Ş., Usta, M., Sipahioğlu H.M., Güller A. 2016. "First report of "Canditatus Phytoplasma solani" on a new host marigold (Tagetes erecta L.)" Turkish Journal of Agriculture and Forestry, 40: 311-318.

Al-Subhi, A.M., Hogenhout, S.A., Al-Yahyai, R.A., AlSadi, A.M. 2017. Classification of a new phytoplasma subgroup $16 \mathrm{Srll}-\mathrm{W}$ associated with Crotalaria witches' broom diseases in Oman based on multigene sequence analysis. BMC Microbiology, 17(1): 221 DOI 10.1186/s12866-017-1130-3.

Alvarez, E., Mejía, J.F., Contaldo, N., Paltrinieri, S., Duduk, B., Bertaccini, A. 2014. 'Canditatus Phytoplasma asteris' strains associated with oil palm lethal wilt in Colombia. Plant Disease, 98: 311-318.

Amaral-Mello, A.P., Bedendo, I.P., Kitajima, E.W., Ribeiro, .LF., Kobori, R. 2006. Tomato big bud associated with a phytoplasma belonging to group $16 \mathrm{Sr}$ III in Brazil, International Journal of Pest Management, 52 (3): 233-237.

\section{Conclusion}

The results of this paper showed that tomatoes were subjected by "Canditatus Phytoplasma solani" and "Canditatus Phytoplasma trifolii", confirmed by 16s rRNA amplification, BLASTN analysis, phylogenetic analysis, and virtual RFLP assays molecularly. This work is the first record on 16SrXII-A group (stolbur) and 16SrVI-A group (clover proliferation) phytoplasma infection of tomato in Bingöl province. Results presented here ensure the important step of an epidemiological investigation on phytoplasma diseases of tomato carried out anywhere in Turkey.

Anfoka, G., Khalil, AB., Fattash, I. 2003. Detection and Molecular Characterization of a Phytoplasma Associated with Big Bud Disease of Tomatoes in Jordan. Journal of Phytopathology, 151(4): 223-227

Arocha, Y., Antesana, O., Montellano, E., Franco, P., Plata, G., Jones, P. 2007. 'Canditatus Phytoplasma lycopersici', a phytoplasma associated with 'hoja de perejil' disease in Bolivia. International Journal of Systematic and Evolutionary Microbiology, 57: 17041710.

Arocha, Y., López, M., Piñol, B., Fernández, M., Picornell, S., Almeida, R., Palenzuela, I., Wilson, M.R., Jones, P. 2005. 'Canditatus Phytoplasma graminis' and 'Canditatus Phytoplasma caricae', two novel phytoplasmas associated with diseases of sugarcane, weeds and papaya in Cuba. International Journal of Systematic and Evolutionary Microbiology, 55: 2451-2463.

Azza, G.F., Eman, A.H.M. 2016. Detection of stolbur phytoplasma in tomato by a specific DNA hybridization. Research Journal of Biotechnology, 11 (6): 30-34.

Belli, G., Bianco, P.A., Conti, M. 2010. Grapevine yellows in Italy: past, present and future. Journal of Plant Pathology, 92(2): 303-326.

Bertaccini, A., Franova, J., Botti, S., Tabanelli, D. 2005 Molecular characterization of phytoplasmas in lilies with fasciation in the Czech Republic. FEMS Microbiology Letters, 249: 79-85.

Bertaccini, A., Duduk, B., Paltrinieri, S., Contaldo, N. 2014. Phytoplasmas and phytoplasma diseases: a severe threat to agriculture. American Journal of Plant Sciences, 5: 1763-1788.

Canik, D., Dikilitas, M., Ertunc, F. 2009. Molecular detection of Pear Decline Phytoplasma in pear trees and their biochemical responses. 87. In: Proceedings 21st Int Conference on 
Virus and Other Graft Trannsmissible Diseases of Fruit Crops, July, 5-10, Neustadt, Germany.

Canik, D., Ertunc, F. 2007. Distribution and molecular characterization of Apple Proliferation phytoplasma in Turkey. Bulletin of Insectology, 60(2): 335-336.

Canik, D., Ertunç, F., Paltrinieri, S., Contaldo, N., Bertaccini, A. 2011. Identification of different phytoplasmas infecting grapevine in Turkey. Bulletin of Insectology, 64: 225S22.

Contaldo, N, Bertaccini, A., Paltrinieri, S., Windsor, H.M., David Windsor, G. 2012. Axenic culture of plant pathogenic phytoplasmas. Phytopathologia Mediterranea, 51: 607617.

Çağlar, B.K., Elbeaino, T. 2013. A novel phytoplasma associated with witches' broom disease of Ligustrum ovalifolium in Turkey. The Journal of Plant Pathology, 137: 113-117.

Çağlar, B.K., Elbeaino, T., Küsek, M., Pehlivan, D., Fidan, H., Portakaldalı, M. 2010. Stolbur Phytoplasma Infections in Potato and Tomato Plants from Different Locations in Turkey. The Journal of Plant Pathology, 39: 1-3.

Çağlayan, K., Gazel, M., Ulubaş Serçe, Ç., Bozkurt, I.A., Elçi, E. 2011. Phytoplasma diseases of stone fruit trees in Turkey and their containment. Phytopathogenic Mollicutes, 1(2): 95-97.

Çarpar, H., Sertkaya, G. 2015. Doğu Akdeniz Bölgesi'nde Fitoplazma Hastalıklarının Durumu. Mustafa Kemal Üniversitesi Ziraat Fakültesi Dergisi, 20(2): 76-82.

Davis, R., Zhao, Y., Dally, E.L., Lee I.M., Jomantiene, R., Douglas, S.M. 2013. 'Canditatus Phytoplasma pruni', a novel taxon associated with X-disease of stone fruits, Prunus spp.: multilocus characterization based on 16S rRNA, secY, and ribosomal protein genes. International Journal of Systematic and Evolutionary Microbiology, 63: 766-776.

Davoodi, A., Panjekeh, N., Moslemkhani, K., Taheri, A. 2019. Detection and molecular characterization of tomato big bud disease in Qazvin province. Journal of Crop Protection, 8(4): 379-388.

Del Serreno, P., Marzachì, C., Bragaloni, M., Galeffi, P. 2001. Phytoplasma infection of tomato in central Italy. Phytopathologia Mediterranea, 40: 137-142.

Deng, S., Hiruki, C. 1991. Amplification of $16 \mathrm{~S}$ rRNA gene genes from culturable and nonculturable mollicutes. The Journal of Microbiological Methods, 14: 53-61.

Dong, J., Zhang, L., Li, W.H., Zhang, Z.K., McBeath, J.H. 2013. 'Canditatus Phytoplasma aurantifolia'-related strain associated with tomato yellows disease in China. Journal of General Plant Pathology, 79(5). DOI: 10.1007/s10327-013-0463-5.

Ember, I., Acs, Z., Munyaneza, JE., Crosslin, JM., Kolber, M. 2011. Survey and molecular detection of phytoplasmas associated with potato in Romania and southern. European Journal of Plant Pathology, 130(3): 367-377.

Flower, C.E., Hayes-Plazolles, N., Slavicek, J.M. 2018. First Report of 'Canditatus Phytoplasma trifolii'-Related Strain of 16SrVIA Phytoplasma Subgroup, Associated with Elm Yellows Disease in American Elm (Ulmus americana L.) in Ohio, U.S.A. Disease Notes, 102 (2): 438

Gazel, M., Çağlayan, K., Başpınar, H., Mejia, J.F., Paltrinieri, S., Bertaccini, A., Contaldo, N. 2016. Detection and Identification of Phytoplasmas in Pomegranate Trees with Yellows Symptoms. Journal of Phytopathology, 164: 136-140.

Gazel, M., Ulubaş Serçe, Ç., Çağlayan, K., Öztürk, H. 2007. Detection of 'Canditatus Phytoplasma pyri' in Turkey. Bulletin of Insectology, 60 (2): 125-126.

Ghayeb Zamharir, M., Aldaghi, M, 2018. First report of a 'Canditatus Phytoplasma trifolii'related strain associated with soybean bud proliferation and seed pod abortion in Iran. New Disease Reports, 37: 15. DOI: 10.5197/j.2044-0588.2018.037.015.

Gopala, Rao GP. 2018. Molecular characterization of phytoplasma associated with four important ornamental plant species in India and identification of natural potential spread sources. 3 Biotech, 8(2):116. doi:10.1007/s13205-018-1126-1.

Hiruki, C., Wang, K.R. 2004. Clover Proliferation Phytoplasma: 'Canditatus Phytoplasma trifolii'. International Journal of Systematic and Evolutionary Microbiology, 54: 13491353.

Hull, R. 1972. Mycoplasma and Plant Disease. PANS, 18 (2): 154-164.

Jovic, J., Cvrkovic, T., Mitrovic, M., Krnjajic, S., Petrovic, A., Redinbaugh, M. G., Pratt, R. C., Hogenhout, S.A., Toševski, I. 2009. Stolbur phytoplasma transmission to maize by Reptalus panzeri and the disease cycle of maize redness in Serbia. Phytopathology, 99(9): 1053-1061. 
Kanatiwela-de Silva, C., Damayanthi, M., de Silva, N., Wijesekera, R., Dickinson, M., Weerakoon, D., Udagama, P. 2019. Immunological detection of the Weligama coconut leaf wilt disease associated phytoplasma: Development and validation of a polyclonal antibody based indirect ELISA. PLoS ONE, 14(4): e0214983.

Krawczyk, K., Pospieszny, H., Kamasa, J. 2010. Identification of New Members of Canditatus Phytoplasma asteris Affecting Tomato Plants in Poland. Journal of Phytopathology, 158: 496-502.

Kumari, S., Nagendran, K., Rai, A.B., Singh, B., Rao, G.P., Bertaccini, A. 2019. Global Status of Phytoplasma Diseases in Vegetable Crops. Frontiers in Microbiology, 10:1349. doi: 10.3389/fmicb.2019.01349.

Lee, I.M., Gundersen-Rindal, D.E., Davis, R.E., Bartoszyk, I.M. 1998. Revised classification scheme of phytoplasmas based on RFLP analyses of $16 \mathrm{~S}$ rRNA and ribosomal protein gene sequences. International Journal of Systematic and Evolutionary Microbiology, 48: 1153-1169.

Liu, Z., Zhao, J., Liu, M. 2016. Photosynthetic responses to phytoplasma infection in Chinese jujube. Plant Physiology and Biochemistry, 105: 12-20.

Lou, B., Bai, X., Bail Y., Deng, C., RoyChowdhury, M., Chen, C., Song, Y. 2013. Detection and Molecular Characterization of a 16Srll-A phytoplasma in Grapefruit (Citrus paradisi) with Huanglongbinglike Symptoms in China. Journal of Phytopathology, 162: 387-395.

Mitrovic, M., Jakovljevic, M., Jovic, J., Krstic, O., Kosovac, A., Trivellone, V., Jermini, M., Toševski, I., Cvrkovic, T. 2016. 'Canditatus Phytoplasma solani' genotypes associated with potato stolbur in Serbia and the role of Hyalesthes obsoletus and Reptalus panzeri (Hemiptera, Cixiidae) as natural vectors. European Journal of Plant Pathology, 144(3): 619-630.

Musetti, R., Buxa, S.V., De Marco, F., Loschi, A., Polizzotto, R., Kogel, K.H., van Bel A.J. 2013. Phytoplasma-triggered $\mathrm{Ca}+$ influx is involved in sieve-tube blockage. Molecular Plant-Microbe Interactions, 26: 379-386.

Nogay, A., Ternar, Ş. 1986. Marmara Bölgesi'nde Domateslerde Görülen Stolbur Hastalığı Üzerinde Araştırmalar. E107.845 No'lu Proje Nihai Raporu. Ziraai Araştırma Enstitüsü. ISTANBUL.

Nogay, A., Ternar, Ş., Ünal, E. 1988. Marmara Bölgesinde Domateslerde Görülen Stolbur
Hastalığı Üzerinde Araştırmalar. Bitki Koruma Bülteni, 28 (1-2): 79-98.

Oksal, H.D., Apak, F.K., Oksal, E., Tursun, N., Sipahioğlu, H.M. 2017. Detection and molecular characterization of two 'Canditatus Phytoplasma trifolii' isolates infecting peppers at the same ecological niche. International Journal of Agriculture and Biology, 19(6): 1372-1378.

Olivier, C., Séguin-Swartz, G., Galka, B., Olfert, O. 2011. Aster yellows in leafhoppers and field crops in Saskatchewan, Canada, 2001-2008. The Americas Journal of Plant Science and Biotechnology, 141: 425-462.

Olmos, A., Cambra, M., Esteban, O., Gorris, M.T., Terrada, E. 1999. New device and method for capture, reverse transcription and nested PCR in a single closed tube. Nucleic Acids Research, 27: 1564-1565.

Oshima, K., Maejima, K., Namba, S. 2013. Genomic and evolutionary aspects of phytoplasmas. Frontiers in Microbiology, 4: 230.

Özdemir, N., Saygılı, H. 2012. A Study On The Transmission With The Seed Of Stolbur Disease In Western Anatolia Tomato Areas. Journal of Agricultural Faculty of Uludag University. 26 (1): 63-72.

Özdemir, N. 2008. Batı Anadolu bölgesi domates üretim alanlarında görülen stolbur hastalığının yaygınlığının belirlenmesi, tanılanması ve taşınma yolları üzerinde çalışmalar. Doktora tezi, Ege Üniversitesi, Ziraat Fakültesi, Bitki Koruma Bölümü, 133 sayfa.

Özdemir, N., Saygılı, H., Sahin, F., Karsavuran, Y., Bayrak, O.F., Oral, B. 2007. Host range and genetic characterization of a phytoplasma causing tomato stolbur disease in Turkey. Second International Symposium on Tomato Diseases (8-12 October, 2007, Kusadası, Turkey) Program and Abstract Book, p. 67.

Özdemir, Z. 2017. "Phytoplasmas of sesame and Orosius orientalis are genetically diverse based on 16S rDNA sequencing and PCRRFLP in Turkey", Archives of Phytopathology and Plant Protection, 50 (13-14): 674-686.

Pérez-López, E., Dumonceaux, T. J., Olivier, C. Y., LunaRodríguez, M. 2014. Identification of 'Canditatus phytoplasma phoenicium' in periwinkle from Cuba. Revista Mexexicana de Fitopatología, 32: 47.

Pracros, P., Renaudin, J., Eveillard, S., Mouras, A., Hernould, M. 2006. Tomato Flower Abnormalities Induced by Stolbur Phytoplasma Infection Are Associated with Changes of Expression of Floral 
Development Genes. Molecular PlantMicrobe Interactions, 19(1): 62-68.

Quaglino, F., Zhao, Y., Casati, P., Bulgari, D., Bianco, P.A., Wei, W., Davis, R.E. 2013. 'Canditatus Phytoplasma solani', a novel taxon associated with stolbur- and bois noirrelated diseases of plants. International Journal of Systematic and Evolutionary Microbiology, 63(8): 2879- 2894.

Reveles-Torres, L.R., Velásquez-Valle, R., SalasMuñoz, S., Mauricio-Castillo, J.A., Caren, K., Esqueda-Dávila, J., Herrera, M.D. 2018. Canditatus Phytoplasma trifolii (16SrVI) infection modifies the polyphenols concentration in pepper (Capsicum annuum) plant tissues. Journal of Phytopathology, DOI: 10.1111/jph.12717.

Sahtiyancı, Ş. 1972. Marmara Bölgesi virus vektörleri üzerine araştırmalar. Zirai Mücadele Araştırma Yıllıkları, 113-114.

Salehi, M., Izadpanah, K., Siampour, M. 2008. First Report of 'Canditatus Phytoplasma trifolii'Related Strain Associated with Safflower Phyllody Disease in Iran. Plant Disease. 92(4): 649.

Santos-Cervantesa, M.E., Chávez-Medinaa, J.A., Fierro-Coronadoa, J.A., Ruelas-Ayalaa, R.D., Barreras-Sotoa, M.A., Méndez-Lozanoa, J., Leyva-Lópeza, N.E. 2007. First report of Canditatus 'Phytoplasma asteris' infecting tomatillo (Physalis ixocarpa) in Sinaloa, México. Plant Pathology, 56: 721

Schneider, B., Cousin, M., Klinkong, S., Seemüller, E. 1995. Taxonomic relatedness and phylogenetic positions of phytoplasmas associated with diseases of faba bean, sunhemp, sesame, soybean and eggplant. Z Pflanzenkr Pflanzenschutz, 102: 225-232.

Schneider, B., Gibb, K.S., Padovan, A.C., Davis, R.I., De La Rue, S. 1999. Comparison and characterisation of tomato big bud and sweet potato little leaf-group phytoplasmas. Journal of Phytopathology, 147: 31-40.

Seemuller, E., Kiss, E., Sule, S., Schneider, B. 2010. Multiple infection of apple trees by distinct strains of 'Canditatus Phytoplasma mali' and its pathological relevance. Phytopathology, 100: 863-870.

Serçe, Ç.U., Yılmaz, S. 2019. First report of 'Canditatus Phytoplasma trifolii' (16SrVI group) infecting cabbage (Brassica oleracea) in Turkey. Journal of Plant Pathology, https://doi.org/10.1007/s42161-019-00443y.

Sertkaya, G., Martini, M., Musetti, R., Osler, R. 2007. Detection and molecular characterization of phytoplasmas infecting sesame and solanaceous crops in Turkey. Bulletin of Insectology, 60: 141-142.

Shahryari, F., Allahverdipour, T., Rabiei, Z. 2019. Phytoplasmas associated with grapevine yellows disease in Iran: first report of a 'Canditatus Phytoplasma trifolii'-related strain and further finding of a "Ca. P. solani"-related strain. New Disease Reports, 40: 17.

Shaw, M.E., Kirkpatrick B.C. 1993. The beet leafhopper-transmitted virescence agent causes tomato big bud disease in California. Plant Disease, 77: 290-295.

Singh, J., Rani, A., Kumar, P., Baranwal, V.K., Saroj, P.L, Sirohi, A. 2012. First report of a 16Srll-D phytoplasma 'Canditatus Phytoplasma australasia' associated with a tomato disease in India. New Disease Reports, 26: 14.

Şahin, F., Özdemir, N., Oral, B., Saygılı, H., Karsavuran, Y., Bayrak, O.F. 2007. Identification of a phytoplasma causing tomato stolbur disease in Turkey. APS. SON. Joint Meeting. Phytopathology S103. July 28- August 1.

Tanrıkut, S. 1953. Domates yetiştiriciliği için tehlikeli bir hastalık. Bitki Koruma Bülteni, 5: 22-28.

Tsplenkov, E.E., Fedotina V.L. 1973. Nature and classification of two forms of Tomato Stolbur. Biologlcheskie. Havkl 16: 100-106 (Rev. PI. Path., 52: 4217).

Ulubas-Serce, C., Gazel, M., Caglayan, K., Bas, M., Son, L. 2006. Phytoplasma diseases of fruit trees in germplasm and commercial orchards. EPPO Bulletin, 36: 216-217.

Ulubas-Serce, C., Kaya, K., Gazel, M., Caglayan, K., Sauvion, N. 2012. Psyllid vectors of AP Group (16SrX) phytoplasmas infecting grapevine in Turkey. 104. In: Book of Abstracts, 22th International Conference on Virus and Other Graft Transmissible Diseases of Fruit Crops, 3-8 June, Rome. 38.

Ulubaş Serçe, Ç., Yılmaz, S. 2019. First report of 'Canditatus Phytoplasma trifolii' (16SrVI group) infecting cabbage (Brassica oleracea) in Turkey. Journal of Plant Pathology, https://doi.org/10.1007/s42161-019-00443$\mathrm{y}$.

Usta, M., Güller, A., Sipahioğlu, H.M. 2017. Detection and Characterization of two Phytoplasma lineages on Cucumber (Cucumis sativus L.) with Same Symptomatology based on Virtual RFLP and Nucleotide Sequence Analysis of 16S rDNA. Yuzuncu Yil University Journal of Agricultural Sciences, 27(3): 299-308. 
Usta, M., Güller, A., Sipahioğlu, H.M. 2018. Molecular analysis of "Canditatus Phytoplasma trifolii" and, Canditatus Phytoplasma solani" associated with phytoplasma diseases of tomato (PDT) in Turkey. International Journal of Agriculture and Biology, 20: 1991-1996.

Valente, V., Musil M., Misiga S. 1961. Investlgations of European yellow styp viruses 1 . the stolbur virus. Phytopathology, 42: 1-38.

Vellios, E., Lioliopoulou, F. 2007. Detection and characterization of phytoplasmas infecting tomato plants in Greece. Bulletin of Insectology. 60(2): 157-158.

Wei, W., Davis, R.E, Lee, I.M., Zhao, Y. 2007. Computer simulated RFLP analysis of $16 \mathrm{~S}$ rRNA genes: identification of ten new phytoplasma groups. International Journal of Systematic and Evolutionary Microbiology, 57: 1855-1867.

Weintraub, P.G, Beanland, L. 2006. Insect vectors of phytoplasmas. Annual Review of Entomology, 51: 91-111.

Weintraub, P.G, Jones, P. 2009. Phytoplasmas, Genomes, Plant Hosts and Vectors. Cab International, United Kingdom. 10.1079/9781845935306.0000

Weisburg, W.G., Tully, J.G., Rose, D.L., Petzel, J.P., Oyaizu, H., Yang, D., Mandelco, L., Sechrest, J., Lawrence, T.G., Van Etten, J. 1989. A phylogenetic analysis of the mycoplasmas: basis for their classification. Journal of Bacteriology, 171: 6455-6467.

Wu, Y., Hao, X., Li, Z., Gu, P., An, F., Xiang, J., Wang, H., Luo, Z., Liu, J., Xiang, Y. 2010. Identification of the phytoplasma associated with wheat blue dwarf disease in China. Plant Disease. 94: 977-985.

Xu, X., Mou, H.Q., Zhu, S.F., Liao, X.L., Zhao, W.J. 2013. Detection and Characterization of Phytoplasma Associated with Big Bud Disease of Tomato in China. Journal of Phytopathology, 161: 430-433.

Yavuz, Ş., Gazel, M., Çağlayan, K. 2019. Determination of apple proliferation phytoplasma disease (Canditatus Phytoplasma mali) in apple orchards in Adana and iç̧el provinces. Mustafa Kemal University Journal of Agricultural Sciences, 24 (1): 15-20.

Yorgancı, Ü., Öncüer, C., Karsavuran, Y. 1991. "Batı Anadolu sanayi domatesi yetiştirme alanlarında stolbur hastalığının yaygınlık oranı ve ortaya çıkış nedenleri üzerinde araştırmalar, s. 315-319". VI. Türkiye Fitopatoloji Kongresi (7-11 Ekim 1991, İzmir)
Bildirileri, Türkiye Fitopatoloji Derneği Yayınları No. 6, $434 \mathrm{~s}$.

Zambon, Y., Canel, A., Bertaccini, A., Contaldo, N. 2018. Molecular Diversity of Phytoplasmas Associated with Grapevine Yellows Disease in North-Eastern Italy. Phytopathology, 108(2): 206-214.

Zhang, L., Li, Z., Du, C., Fu, Z., Wu, Y. 2012. Detection and Identification of Group 16SrVI Phytoplasma in Willows in China. Journal of Phytopathology, 160: 755-757.

Zhao, Y., Wei W., Lee I.M., Shao J., Suo X., Davis R.E. 2009. Construction of an interactive online phytoplasma classification tool, iPhyClassifier, and its application in analysis of the peach X-disease phytoplasma group (16SrIII). International Journal of Systematic and Evolutionary Microbiology, 59: 25822593. 